\title{
Pola Hubungan Fraksi Dengan Lembaga Dewan Perwakilan Rakyat Republik
}

\author{
Indonesia Pasca Reformasi \\ Fathan Ali Mubiina ${ }^{1}$ \\ Universitas Indonesia \\ Jl. Salemba Raya IV, RW.5, Kenari, Kec. Senen, \\ Kota Jakarta Pusat, Daerah Khusus Ibukota Jakarta 10430 \\ fathanalim03@gmail.com \\ Masuk: 4 Febuari 2020; Diterima: 27 Mei 2020; Terbit: 29 Mei 2020. \\ DOI : $10.24905 /$ diktum.v8i1.80
}

\begin{abstract}
Purpose of research to analyse The role of political parties is as a strategic forum in the political system in Indonesia to connect between the process of forming government policies both in the executive and in the legislature with its citizens. In fact, it is precisely the political parties that determine whether or not the democratic system is established in Indonesia. Because in political parties there is a form of institutionalization which is an expression of free ideas, thoughts, views and beliefs in a democratic society. Then the political parties also according to the legislation in force in the history of the development of post-reform political parties are functioning as political education, absorbing, channeling and fighting for the interests of the community, as well as preparing community members to fill political positions in accordance with democratic mechanisms in Indonesia through representative democracy. The pattern of relations between political parties and the Republic of Indonesia Parliament is quite simple, namely that political parties have the right to participate in the legislative election process in the legislative. This legal research used prescriptive, this legal research is conducted to solve the law enforcement issues faced.
\end{abstract}

Keywords : Political Parties, Parliament, and Electoral. Legislative

\begin{abstract}
Abstrak
Tujuan penelitian adalah untuk menganalisa Peranan partai politik ialah sebagai wadah yang strategis dalam sistem politik di Indonesia guna penghubung antara proses pembentukan kebijakan pemerintah baik di eksekutif maupun di legislatif dengan warga negaranya. Sesungguhnya justru partai politiklah yang menentukan terselenggara atau tidaknya sistem demokrasi di Indonesia. Sebab dalam partai politik terdapat bentuk pelembagaan wujud ekspresi ide-ide, pikiran-pikiran, pandangan, dan keyakinan bebas dalam masyarakat yang demokratis. Kemudian partai politik juga menurut peraturan perundang-undangan yang berlaku dalam sejarah perkembangan partai politik pasca reformasi ialah berfungsi sebagai pendidikan politik, menyerap, menyalurkan dan memperjuangkan kepentingan masyarakat, serta mempersiapkan anggota masyarakat untuk mengisi jabatan-jabatan politik sesuai dengan mekanisme demokrasi yang ada di Indonesia melalu demokrasi perwakilan. Pada pola hubungan antara partai politik dengan Dewan Perwakilan Rakyat Republik Indonesia cukup sederhana, yaitu partai politik memiliki hak untuk ikut serta dalam proses pemilihan umum anggota legislatif di Dewan Perwakilan Rakyat Republik Indonesia. Penelitian hukum ini bersifat preskriptif, yang dilakukan untuk memecahkan isu penegakan hukum yang dihadapi
\end{abstract}

Kata Kunci : Partai Politik, Parlemen, dan Pemilihan Umum, Dewan Perwakilan Rakyat 


\section{A. Pendahuluan}

Hubungan antara pemerintahan (state) dengan warga negara/rakyat (society) seharusnya selalu berada dalam bingkai interaksi politik diantara keduanya dalam wujud organisasi negara. Hubungan state and society ini dapat tergambarkan dalam icon yang diberi label demokrasi. Sejak lama, sebagai gambaran besar, demokrasi menjadi cara terbaik dalam perkembangan organisasi negara modern. Demokrasi yang dimaksud merupakan instrumen universal. Demokrasi sebagai aspek penting berkaitan dengan pemerintahan dengan hirarki kekuasaan yang terdapat dalam suatu sistem politik negara. Artinya, akan terdapat sistem politik nasional dalam bingkai sistem negara yang dianutnya.

Demokrasi memberikan peluang bagi pemerintahan dalam arti luas yakni eksekutif maupun legislatif dalam mengembangkan kehidupan hubungan pemerintahan (arti luas) dengan rakyat di negaranya. ${ }^{1}$ Semenjak pada pemilu legislatif pertama tahun 1955, demokrasi yang dibentuk telah mengarah pada demokrasi partisipatif atau langsung untuk memberikan legitimasi yang kuat bagi para anggota dewan saat itu dengan melibatkan unsur partai politik sebagai kendaraan bagi masyarakat untuk terlibat dalam Dewan Perwakilan Rakyat. Oleh sebab itu, partai politik sebagai sarana bagi warga negara dalam rangka untuk ikut serta dalam pengelolaan negara. Di sisi lain, sejarah kelahiran partai politik di Indonesia cukup panjang. Perlu diketahui bahwa partai politik pada pertama kali lahir di negara-negara Eropa barat, dengan meluasnya gagasan bahwa rakyat merupakan faktor yang perlu diperhitungkan serta diikutsertakan dalam proses politik, maka partai politik telah lahir secara spontan dan berkembang menjadi penghubung antara rakyat di satu pihak dan pemerintah di pihak lain. ${ }^{2}$

\footnotetext{
${ }^{1}$ Inu Kencana Syafiie, Pengantar Ilmu Pemerintahan, Bandung: Refika Aditama. 2001 ,hlm.20.

${ }^{2}$ Miriam Budiardjo, Partisipasi Dan Partai Politik: Sebuah Bunga Rampai, Jakarta: Gramedia, 1982, hlm. 397.
} 
Lalu perkembangan partai politik di Indonesia memiliki sejarah pertama kali lahir pada zaman kolonial sebagai bentuk manifestasi bangkitnya kesadaran persatuan bangsa untuk melawan bentuk kolonialisme dari bangsa Deutsch (Belanda). Berbagai organisasi modern bermunculan sebagai wadah pergerakan nasional untuk mencapai kemerdekaan. Walaupun pada awalnya berbagai organisasi tidak secara tegas menamakan diri sebagai partai politik, namun memiliki program-program serta aktivitas politik.

Kelahiran Budi Utomo merupakan contoh dari terbentuknya organisasi nasional pada masa kolonial tersebut dan juga cikal bakal lahirnya organisasi modern di Indonesia, maka dari itu tidak heran apabila kelahiran Budi Utomo diidentikan sebagai tonggak kebangkitan nasional. Lahirnya Budi Utomo pada awalnya disebabkan oleh kondisi bangsa Indonesia yang saat itu berada dalam jajahan Belanda. Dimana rakyat berada dalam kondisi menderita dan disiksa. Hanya sebagian pemuda dan pelajarlah yang menikmati pendidikan, akan tetapi hanya sebagian kecil pemuda yang menikmati pendidikan tersebut yang sadar akan kondisi kesengsaraan bangsa Indonesia. Sehingga atas dasar itu pemudapemuda tersebut mendirikan perkumpulan Budi Utomo dengan tujuan untuk memajukan rakyat dalam bidang ekonomi, pendidikan dan kebudayaan. ${ }^{3}$

Keberadaan organisasi tersebut di ikuti dengan munculnya berbagai organisasi partai politik. Partai-partai tersebut diantaranya adalah Indische Partij (IP), Indische Social Democratische Vereeniging (ISDV), Partai Komunis Indonesia (PKI), Partai Nasional Indonesia (PNI), Partai Indonesia Raya (Perindra), Gerakan Rakyat Indonesia (Gerindro), Partai Indonesia (Pertindo), dan Partai Rakyat Indonesia (PRI). Indische partij merupakan partai politik pertama di Indonesia yang menjadi pelopor timbulnya organisasi-organisasi politik di zaman pra kemerdekaan, baik organisasi politik yang bersifat ilegal maupun legal. ${ }^{4}$

\footnotetext{
3 Slamet Muljana, Nasionalisme Sebagai Modal Perjuangan, Jakarta: Balai Pustaka, 1968, hlm.114.

4 Pk. Poerwanta, Partai Politik Di Indonesia, Jakarta: Rineka Cipta, 1994, hlm. 35.
} 
Mengingat ekstrimnya pemikiran partai ini kala itu, Indische Partij hanya bertahan delapan bulan saja, hal itu disebabkan karena ketiga pemimpin mereka masingmasing dibuang ke Kupang, Banda dan Bangka, dan kemudian diasingkan ke Belanda. ${ }^{5}$

Setelah beberapa tahun diasingkan, Ki Hajar Dewantara dan Setyabudi kembali ke Indonesia untuk mendirikan partai politik yang dinamakan sebagai National Indische Partij (NIP) pada tahun 1919 yang kemudian secara langsung mempelopori lahirnya beberapa partai politik lain yakni Indische Social Democratische Verening (ISDV), Partai Nasional Indonesia, Partai Indonesia dan Partai Indonesia Raya. ${ }^{6}$ Partai-partai politik yang ada sebelum kemerdekaan tersebut, tidak semuanya mendapatkan status badan hukum dari kolonial Belanda. Bahkan, partai-partai tersebut tidak dapat beraktivitas secara damai dan lancar di zaman kolonial Belanda. Maka dari itu, partai yang bergerak atau menentang tegas pemerintahan belanda akan dilarang, dimana pemimpinnya akan ditangkap, dipenjarakan atau diasingkan.

Kemudian, setelah perjalanan historis, timbullah jaminan kemerdekaan berserikat yang diberikan oleh negara Indonesia melalui UUD 1945. Negara menjamin secara tegas dalam Pasal 28 E ayat 3 UUD 1945, yaitu:

"Setiap orang berhak atas kebebasan berserikat, berkumpul, dadn mengeluarkan pendapat."

Berdasarkan ketentuan tersebut apabila memahami hakikatnya, maka pasal a quo memiliki substansi yang jauh lebih tegas mengenai kebebasan berserikat yang menjadi dasar bagi Partai Politik di era pasca reformasi. Meskipun dasar konstitusi sebelum amandemen ketentuan di dalam Pasal 28 UUD 1945 (asli) memiliki kandungan makna yang lebih dalam, yaitu:

\footnotetext{
${ }^{5}$ Chotib, dsb., Kewarganegaraan 2: Menuju Masyarakat Madani, Jakarta: Yudhistira, 2007, hlm. 8.

6 Slamet Muljana, Op Cit., hlm. 97.
} 
“Kemerdekaan berserikat dan berkumpul, mengeluarkan pikiran dengan

lisan dan tulisan dan sebagainya ditetapkan dengan undang-undang."

Oleh sebab itu, hak berserikat, berkumpul, dan mengeluarkan pendapat yang dirumuskan dalam Pasal 28 E UUD 1945 (Setelah amandemen) harus dijamin oleh negara dalam hal perlindungan dan penghormatan serta pengembangan dalam rangka peri kehidupan bermasyarakat, berbangsa, dan bernegara yang demokratis.

Sebelum jauh membedah hubungan partai politik dengan DPR RI, seperti yang dijelaskan oleh Jimly Asshiddiqie bahwa partai politik adalah asosiasi warga negara (rechts persoon). Namun sebagai badan hukum, partai politik tidak dapat beranggotakan seperti badan hukum lain. Yang hanya dapat menjadi anggota badan hukum partai politik ialah perseorangan warga negara sebagai subjek hukum naturlijke persoon yang memenuhi kriteria keanggotaan partai. Status partai politik sebagai badan hukum sangat penting dalam hubungannya dengan kedudukan partai politk sebagai subjek lalu lintas hukum. Tertuama untuk membedah peranan dan fungsi partai politik dalam hubungannya dengan lembaga-lembaga negara.

Dari sepenggal sejarah dan hak berserikat atas pembentukan partai politik sebelum kemerdekaan Indonesia berdasarkan UUD 1945 dengan berbagai kandungan perlindungan jaminan tersebut, maka dari itu yang perlu digali lebih mendalam ialah hubungan kausalitas antara partai politik dengan kekuasaan khususnya kekuasaan legislatif orde baru hingga masa pasca reformasi dengan berbagai perkembangannya. Berdasarkan apa yang telah dijelaskan di atas, munculah rumusan Pasal 19 Bab VII UUD 1945 (Asli) dan Setelah Amandemen, dimana sebelum amandemen UUD 1945 bahwa Pasal 19 menyangkut Susunan Dewan Perwakilan Rakyat ditetapkan oleh undang-undang. Kemudian, Pasca amandemen UUD 1945 pada Pasal 19 menjelaskan bahwa anggota DPR dipilih 
melalui pemilihan umum serta di ayat 2 nya bahwa susunan DPR ditetapkan oleh undang-undang.

Berdasarkan hal tersebut untuk menyusun tulisan yang komprehensif maka pada tulisan ini menggunakan pendekatan historical dan pendekatan statutes untuk membedah peran serta partai politik dalam hubungannya pada lembaga Dewan Perwakilan Rakyat Republik Indonesia. Oleh sebab itu, keberadaan partai politik tidak boleh serta merta ditiadakan begitu saja, disebabkan perjalanan historinya yang cukup panjang terutama juga pada masa pasca kemerdekaan di Indonesia. Sehingga, tulisan ini mengangkat topik hubungan partai politik bagi lembaga Dewan Perwakilan Rakyat Republik Indonesia, dengan beberapa pokok permasalahan yang perlu ditelaah ialah perkembangan peran dan fungsi partai politik berdasarkan perundang-undangan yang berlaku, serta menggali sisi hubungan partai politik dengan lembaga Dewan Perwakilan Rakyat Republik Indonesia berdasarkan perundang-undangan yang berlaku.

\section{B. Rumusan Masalah}

1. Bagaimana hubungan partai politik dalam sistem kelembagaan di DPR berdasarkan rezim Undang-Undang Pemilu yang pernah dan sedang berlaku di Indonesia pasca reformasi?

2. Bagaimana peranan dan fungsi fraksi dalam sistem demokrasi berdasarkan perundang-undangan yang berlaku di Indonesia?

\section{Pembahasan}

\section{Pola Hubungan Partai Politik dalam Sistem Kelembagaan Di DPR}

\section{Berdasarkan Rezim Undang-Undang Pemilu}

Mengawali pembahasan hubungan partai politik dengan lembaga DPR RI tentulah melihat dahulu dari sisi historis mengenai demokrasi langsung. Demokrasi langsung sebagaimana pelaksanaannya di zaman Yunani Kuno sangatlah rumit dan sulit untuk dapat dipertahankan, hal ini sesuai dengan 
keinginan J.J. Rousseau dengan tetap melanjutkan demokrasi langsung (direct democracy) dalam sistem kenegaraan di seluruh dunia. Namun, sebagaimana yang terjadi di Indonesia dengan wilayah negara yang luas, kemudian total populasi masyarakat Indonesia 260 (dua ratus enam puluh) juta penduduk telah timbul kesulitan dan kerumitan dalam hal persoalan penanganan sengketa politik di tingkat nasional. Kemudian, dalam sistem politik pada negara seperti Indonesia saat ini sesungguhnya rakyat menyelenggarakan kedaulatan yang dimilikinya melalui wakil-wakil yang dipilihnya secara berkala. ${ }^{7}$ Setelah itu, untuk menjawab tantangan zaman, maka timbulah perkembangan gagasan tentang demokrasi langsungnya J.J. Rousseau yang mengalami sedikit perubahan, yaitu lahirnya lembaga perwakilan atau terkenal dengan istilah parlemen sebagai bentuk pengejawantahan ide tentang demokrasi perwakilan (representative democracy). ${ }^{8}$ Perwakilan atau representation yang dikenal sejak awal ialah perwakilan yang bersifat politik (political representation) yang mana perwakilan rakyat di parlemen melalui partai politik memiliki kemampuan untuk berbicara dan bertindak atas nama rakyat atau konsituen yang memilih partai tersebut.

Kemudian, bahwa terdapat pandangan yang sekiranya menjadi acuan keberlangsungan hubungan antara partai politik dengan DPR RI sebagaimana mengacu pada pandangan Padmo Wahjono yang mengungkapkan bahwa timbulnya konstruksi perwakilan disebabkan oleh tiga hal sesuai dengan ide Jellinek sebagai berikut:

1. Pengaruh berkembangnya hukum perdata Romawi di abad pertengahan yang menyebabkan timbulnya sistem perwakilan.

\footnotetext{
${ }^{7}$ Miriam Budiardjo, Dasar-Dasar Ilmu Politik, Jakarta: Gramedia, 1991, hlm. 174.

${ }^{8}$ Ibid.
} 
2. Adanya sifat dualistis pada abad menengah yaitu adanya hak raja dan hak rakyat. Hal ini mengakibatkan timbulnya perwakilan untuk mencerminkan hak rakyat.

3. Pada abad menengah sekalipun tuan-tuan tanah merupakan pusat kekuasaan. Permasalahannya ialah kekuasaan pada masa Romawi tersebut diperebutkan antar tuan tanah, yang sesungguhnya rakyat tidak pernah mendapatkan andil dalam perebutan kekuasaan. ${ }^{9}$

Setelah itu, untuk mendukung pemahaman mengenai perwakilan, masih terdapat lagi teori mengenai hubungan antara si wakil rakyat dengan rakyat sebagai pemberi mandat, teori ini disebut teori mandat. Teori mandat ini dalam ilmu pengetahuan tentang kenegaraan dikenal dengan beberapa istilah, yaitu:

1. Teori Mandat Imperatif, si wakil sudah mendapat instruksi dari yang diwakili, kewenangan si wakil amat sangat terbatas, yaitu pada apa yang ditentukan atau diinstruksikan oleh yang diwakili.

2. Teori Mandat Bebas, si wakil memiliki kebebasan dalam menentukan apa yang akan dilakukan di lembaga perwakilan (DPR RI). Sehingga, tidak tergantung pada instruksi yang diwakilkan.

3. Teori Mandat Representatif, rakyat sebagai pemegang kedaulatan dan sudah memiliki kesadaran bernegara. Selanjutnya rakyat memberikan mandatnya pada badan perwakilan secara keseluruhan untuk melaksanakan kedaulatan rakyat tersebut. Si wakil tidak memiliki hubungan langsung dan tidak bertanggungjawab pada yang diwakili. ${ }^{10}$

Kemudian setelah itu, bahwa dalam penerapan teori mandat yang berhubungan dengan perkembangan sistem politik di Indonesia.

\footnotetext{
9 Padmo Wahjono, Kuliah-Kuliah Ilmu Negara, Jakarta: Ind-Hill. Co., 1996, hlm. 186.

${ }^{10}$ Makmur Amir dan Reni Dwi Purnomowati, Lembaga Perwakilan Rakyat, Jakarta: Pusat Hukum Tata Negara Fakultas Hukum Universitas Indonesia, 2005, hlm. 12.
} 
Perkembangan sistem politik yang perlu dihighlight ialah pada konstruksi sistem politik Orde Baru yang mana beralaskan pada upaya untuk melakukan pemulihan situasi keamanan dan penciptaan stabilitas politik di tahun 1965 hingga 1998. Presiden Soeharto pada saat itu menjaga stabilitas sistem politik dengan menekan perbedaan ideologi yang ada di masyarakat, sehingga partai-partai yang ada pada era Orde Lama dikelompokkan dalam kemiripan ideologi seperti ideologi Agamis dengan ideologi nasionalis. Sebelum dilaksanakannya pemilu tahun 1971, pemerintah Orde Baru saat itu melakukan upaya untuk mengontrol lembaga DPR. Misalnya, dari 460 orang anggota DPR, 100 orang diantaranya ialah tidak dipilih dalam proses pemilu, melainkan diangkat dari unsur angkatan bersenjata atau ABRI. Kesepakatan politik saat itu melahirkan komposisi DPR seperti itu, kesepakatan politik dilakukan antara pemerintah dengan partai-partai politik, yaitu Partai PDI, Partai PPP, dan Golongan Karya. ${ }^{11}$

Pada saat itu memang pemerintah mengajukan sistem yang digunakan dalam pemilu adalah sistem distrik, yang mana acuan menggunakan sistem distrik tersebut dimaksudkan untuk menyederhanakan partai secara alamiah dan hanya akan memunculkan dua partai besar. Namun, dari pihak partai politik lebih menghendaki untuk penggunaan sistem proporsional dalam sistem pemilihan. ${ }^{12}$ Seperti halnya tabel berikut ini, yang menggambarkan kondisi pemilihan umum pada masa Orde Baru sebagai berikut:

Tabel 1. Jumlah Suara Yang Sah Dan Tidak Sah Dibandingkan Dengan

\author{
Jumlah Pemilih
}

\footnotetext{
${ }^{11}$ T.A. Legowo (ed), Lembaga Perwakilan Rakyat di Indonesia: Studi Analisis Sebelum dan Setelah Perubahan UUD 1945 (Kritik, Masalah, dan Solusi), Jakarta: FORMAPI, 2005, hlm. 28.

12 Sistem Distrik terinspirasi dari Duverger's Law. Kecil kemungkinan peluang untuk mendapatkan kursi di DPR, maka akan memaksa partai-partai kecil untuk bergabung. Miriam Budiardjo, Sistem Pemilu yang Bagaimana dalam Abdul Bari Azed (ed), Sistem-sistem Pemilihan Umum: Suatu Himpunan Pemikiran, Jakarta: BPFH UI, 2000, hlm. 33-34.
} 
'DIKTUM: JURNAL ILMU HUKUM

ISSN: 2655-3449 (E) - 2338-5413 (P) | Volume 8 No. 1 | Mei 2020 GEDUNG Q FAKULTAS HUKUM UNIVERSITAS PANCASAKTI TEGAL J. Halmahera Km. 01, Kota Tegal | Telepon: (0283) 358745 Website: www.diktum.upstegal.ac.id | email: diktum@upstegal.ac.id

\begin{tabular}{|c|c|c|c|c|c|}
\hline Tahun & $\begin{array}{c}\text { Pemilih } \\
\text { Terdaftar }\end{array}$ & Suara Sah & $\%$ & $\begin{array}{c}\text { Suara } \\
\text { Tidak Sah }\end{array}$ & $\%$ \\
\hline 1977 & $70,378,750$ & $63,998,344$ & 90,94 & $6,380,406$ & 9,06 \\
\hline 1982 & $81,629,250$ & $75,126,306$ & 92,04 & $6,502,944$ & 7,96 \\
\hline 1987 & $93,965,953$ & $85,809,818$ & 91,33 & $8,156,137$ & 8,67 \\
\hline 1992 & $107,565,697$ & $97,789,534$ & 90,92 & $9,776,163$ & 9,08 \\
\hline 1997 & $124,740,987$ & $112,991,160$ & 90,58 & $12,519,032$ & 9,42 \\
\hline
\end{tabular}

Sumber: Pemilihan Umum 1997, Perkiraan Harapan dan Evaluasi

Tabel 2. Jumlah Peroleh Suara Partai Politik

Dalam Pemilu 1971-1987

\begin{tabular}{|c|c|c|c|c|}
\hline $\begin{array}{c}\text { Partai } \\
\text { Politik/Peserta } \\
\text { Pemilu }\end{array}$ & 1971 & 1977 & 1982 & 1987 \\
\hline Golkar & 62,8 & 62,1 & 64,3 & 73,2 \\
\hline PPP & 27,1 & 29,3 & 27,2 & 16 \\
\hline PDI & 10,1 & 8,6 & 7,9 & 10,9 \\
\hline Total & 100 & 100 & 100 & 100 \\
\hline
\end{tabular}

Sumber: R William Liddle, Pemilu-Pemilu Orde Baru

Sesungguhnya pada proses penyelenggaraan pemilu era Orde Baru sangat teratur tingkat partisipasi masyarakat hampir 100\% setiap tahun pemilihan umum, namun hal yang sangat disayangkan ialah pelanggaran yang dilakukan pemerintah dengan berpihak pada Golkar melalui struktur administrasi dan kekuatan keamanan, serta mengendalikan lembaga pemilihan umum. ${ }^{13} \mathrm{Hal}$ tersebut menjadikan rakyat tidak berdaulat disebabkan banyaknya anggota

${ }^{13}$ R. William Liddle, Pemilihan Umum 1971: Pandangan dari Desa, (Ohio: Tanpa tahun), hlm. 14. Lihat juga di T.A. Legowo (ed.), Lembaga Perwakilan Rakyat di Indonesia: Studi Analisis Sebelum dan Setelah Perubahan UUD 1945 (Kritik, Masalah, dan Solusi), Op. Cit., hlm. 30. 
parlemen yang diangkat, control rezim Orde Baru terhadap partai politik, dan kebijakan depolitisasi rakyat, yaitu menjauhkan mereka dengan partai politik dan wakil rakyat di parlemen. Pada era Orde Baru, Undang-Undang Pemilu dan Undang-Undang Kepartaian melarang partai membentuk cabang-cabang di bawah tingkat provinsi. Hal ini tentu merugikan bagi partai politik dalam hal berhubungan dengan rakyat sebagai media aspirasi rakyat di parlemen. Keterwakilan rakyat dengan menggunakan sistem pemilu perwakilan berimbang dengan stelsel daftar telah memberikan kemungkinan bagi perwakilan organisasi dalam masyarakat untuk memiliki wakil dalam lembaga DPR RI.

Kemudian, dalam hal membicarakan hubungan partai politik dengan DPR RI, berarti membicarakan mengenai partisipasi rakyat di lembaga perwakilan rakyat. Sesungguhnya dalam negara demokrasi perwujudan partisipasi rakyat salah satunya ialah mengikuti pemilihan umum untuk memilih calon anggota DPR RI dari partai politik yang telah lolos verifikasi sebagai peserta pemilu. Setelah itu, hubungan rakyat dengan DPR RI dalam pola ketatatnegaraannya ialah hubungan antara wakil rakyat dengan masyarakat yang diwakilinya. Maka, dari situlah peran partai politik sebagai penghubung antara aspirasi rakyat dengan lembaga DPR RI, yang mana di dalam lembaga DPR RI terdapat fraksifraksi partai politik yang berfungsi sebagai wadah aspirasi masyarakat yang nyata. Oleh sebab perjalanan historis perkembangan hubungan tersebut cukup panjang, maka dalam hal pembahasan mengenai hubungan partai politik dengan DPR RI dibatasi hanya pada pembedahan hubungan partai politik dengan DPR pada masa pasca reformasi. Selanjutnya, berikut ini pembagian masa pasca reformasi berdasarkan Undang-Undang Pemilu, Undang-Undang MD3, dan Undang-Undang Partai Politik.

2. Peranan Dan Fungsi Fraksi Dalam Sistem Demokrasi Berdasarkan PerundangUndangan Yang Berlaku Di Indonesia

1. DPR RI Periode 1999-2004 
Pemilu 1999 ialah sebagai bagian yang penting dalam proses penyelesaian reformasi di tahun 1998, perubahan terhadap Undang-Undang Pemilu menjadi awal dari proses pembaharuan sistem politik di Indonesia. Pada saat itu harapan dari masyarakat yaitu menjadikan Pemilu 1999 lebih memiliki kualitas dalam menghasilkan wakil-wakil rakyat dengan prinsip langsung, umum, bebas, rahasia, jujur, dan adil. Jaminan tersebut terwujud dalam hal perubahan mendasar pada pengaruh pengangkatan ABRI secara politis dibandingkan dengan masa sebelumnya. Beberapa perubahan yang terjadi relatif membuka kesempatan kepada anggota dewan untuk lebih terbuka dan transparan. Mekanisme pembuatan keputusan di DPR RI dengan mekanisme voting suara terbanyak telah menjadi solusi yang lazim untuk digunakan, sebab keputusan yang dibuat sudah semestinya memiliki legitimasi yang kuat pula.

Kemudian, yang cukup menarik pada DPR RI masa 1999 hingga 2004 ini menghilangkan hak recall yang dilakukan oleh partai politik. ${ }^{14}$ Hal tersebut bertujuan untuk menghindari oligarki-sentralistik pada elit partai. ${ }^{15}$ Adanya perubahan mendasar pada hubungan partai politik mengenai recall menjadikan kedudukan anggota DPR RI itu sendiri lebih dapat berdaulat dan bersifat independen, tanpa adanya intervensi yang dilakukan pemerintah

${ }^{14}$ Indonesia, Undang-Undang No. 4 Tahun 1999 tentang Susunan Kedudukan MPR, DPR, dan DPRD, Pasal 14. Dalam rezim undang-undang ini tidak lagi mencantumkan proses penggantian antar waktu yang disebabkan oleh usulan dari partai politik pengusung anggota dewan di DPR RI. Namun, klasul pasal tentang hak recall partai politik yang sebelumnya ada di Pasal 14 UndangUndang No. 16 Tahun 1969 jo Undang-Undang No. 5 Tahun 1995 tentang Susduk MPR, DPR, dan DPRD dirubah menjadi ketentuan Pasal 14 dan Pasal 42 Undang-Undang No. 4 Tahun 1999 dengan pelanggaran yang dilakukan oleh anggota DPR RI yang kedapatan melakukan usaha atau kegiatan yang menguntungkan pribadinya dengan uang yang berasan dari APBN.

${ }^{15}$ T.A. Legowo (ed), Lembaga Perwakilan Rakyat di Indonesia: Studi Analisis Sebelum dan Setelah Perubahan UUD 1945 (Kritik, Masalah, dan Solusi), Jakarta: FORMAPI, 2005, Op. Cit., hlm. 34. 
maupun partai politiknya sendiri. ${ }^{16}$ Namun, sayangnya peubahan sistem politik pada tahun 1999 tidak membawa perubahan yang berarti terkait kualitas lembaga DPR RI. Kinerja anggota dewan yang mengecewakan membuktikan adanya kelemahan dalam sistem perwakilan politik di Indonesia.

Pengalaman sejarah dalam hal memperlihatkan representasi politik rakyat amat ditentukan oleh struktur dan mekanisme pengaturannya. Kemudian, pengalaman Indonesia menerapkan lembaga parlemen dapat dideskripsikan secara sederhana bahwa model perwakilan Indonesia pada masa 1999 hingga 2004 tidak terlampau jauh berbeda dengan periode sebelumnya. Masih terjadinya negosiasi antar kekuatan politik demi melanggengkan perjuangan agenda kepentingan masing-masing. Berikut ini tabel yang membuktikan kecilnya tanggung jawab terhadap rakyat pada masa 1999-2004.

\section{Tabel 3. Kategorisasi Atas Pembabakan Sejarah}

Perwakilan di Indonesia ${ }^{17}$

\begin{tabular}{|c|c|c|c|c|}
\hline \multirow{2}{*}{ Periode } & Dasar & Sistem & Tanggung & Tanggung \\
& Perwakilan & Pemilihan & Terhadap \\
Jawab \\
Terhadap \\
1965-1998
\end{tabular}

\footnotetext{
${ }^{16}$ Sejak tahun 1999 hingga sebelum bergantinya Undang-Undang Pemilu dengan Undang-Undang No. 12 Tahun 2003, hak recall tidak dimiliki oleh partai politik. Sehingga, partai politik tidak dapat memberhentikan anggota dewan yang berasal dari partainya pada masa ini.

17 T.A. Legowo (ed), Op. Cit., hlm. 35.
} 


\begin{tabular}{|c|c|c|c|c|}
\hline & $\begin{array}{c}\text { Karya }+ \\
\text { Pengangkatan } \\
\text { ABRI }\end{array}$ & & \\
\hline $1999-2004$ & $\begin{array}{c}\text { Pemilihan } \\
\text { DPR dari }\end{array}$ & & & \\
& Unsur Parpol & Proporsional & Kecil & Kecil \\
& Pengangkatan & Tertutup & & \\
& ABRI & & & \\
\hline
\end{tabular}

Sumber: FORMAPPI

Kemudian menyangkut hubungan antara partai politik dengan DPR RI pada periode 1999-2004 berdasarkan peraturan perundang-undangan yang berlaku sebagai berikut:

Tabel 4. Kategorisasi Hubungan Partai Politik dengan DPR RI Periode $1999-2004^{18}$

\begin{tabular}{|c|c|}
\hline $\begin{array}{c}\text { Perundang- } \\
\text { undangan }\end{array}$ & Hubungan DPR RI dengan Partai Politik \\
\hline UU No. 4 & $\begin{array}{l}\text { 1. Kuota DPR RI sebanyak 462 kursi untuk } \\
\text { Partai Politik (Pemilihan Umum), sisanya } \\
\text { Tahun 1999 }\end{array}$ \\
$\begin{array}{c}\text { sebanyak 38 ABRI yang diangkat. } \\
\text { tentang }\end{array}$ & $\begin{array}{l}\text { Partai Politik tidak memiliki Hak recall. } \\
\text { Susduk MPR, } \\
\text { DPR, dan }\end{array}$ \\
DPRD & $\begin{array}{l}\text { Fraksi yang memiliki urutan besarnya } \\
\text { kesempatan untuk dipilih menjadi }\end{array}$ \\
\hline
\end{tabular}

${ }^{18}$ Tabel 4 ini disusun berdasarkan rumusan unsur ada atau tidak adanya hubungan antara partai politik dengan DPR RI yang termuat dalam Undang-Undang No. 4 Tahun 1999 tentang Susduk MPR, DPR, dan DPRD, Undang-Undang No. 2 Tahun 1999 tentang Partai Politik, dan Undang-Undang No. 3 Tahun 1999 tentang Pemilu. Hal yang mendasar dalam periode 1999 hingga 2004 ini, partai politik tidak memiliki hak recall. 


\begin{tabular}{|c|c|}
\hline & $\begin{array}{l}\text { pimpinan DPR, yang terdiri dari seorang } \\
\text { ketua, dan sebanyak-banyaknya } 4 \text { (empat) } \\
\text { wakil pimpinan DPR RI. }\end{array}$ \\
\hline $\begin{array}{c}\text { UU No. } 2 \\
\text { Tahun } 1999 \\
\text { tentang } \\
\text { Partai Politik }\end{array}$ & $\begin{array}{l}\text { 1. Partai Politik memliki hak untuk } \\
\text { mengikuti pemilihan umum calon anggota } \\
\text { DPR RI. }\end{array}$ \\
\hline $\begin{array}{c}\text { UU No. } 3 \\
\text { Tahun } 1999 \\
\text { tentang } \\
\text { Pemilihan } \\
\text { Umum }\end{array}$ & $\begin{array}{l}\text { 1. Partai Politik dapat menjadi peserta } \\
\text { Pemilihan Umum apabila memenuhi } \\
\text { syarat-syarat sebagai berikut: } \\
\text { a. diakui keberadaannya sesuai dengan } \\
\text { Undang-undang tentang Partai } \\
\text { Politik; } \\
\text { b. memiliki pengurus di lebih dari } 1 / 2 \\
\text { (setengah) jumlah propinsi di } \\
\text { Indonesia; } \\
\text { c. memiliki pengurus di lebih dari } 1 / 2 \\
\text { (setengah) } \\
\text { kotamadya di propinsi sebagaimana } \\
\text { dimaksud pada huruf b; } \\
\text { d. mengajukan nama dan tanda gambar } \\
\text { partai politik. } \\
\text { (dua per seratus) dari jumlah kursi DPR } \\
\text { (tiga per seratus) jumlah kursi DPRD I atau }\end{array}$ \\
\hline
\end{tabular}




\begin{tabular}{|l|l|}
\hline DPRD II yang tersebar sekurang- \\
kurangnya di $1 / 2$ (setengah) jumlah propinsi \\
dan di $1 / 2 \quad$ (setengah) jumlah \\
kabupaten/kotamadya seluruh Indonesia \\
berdasarkan hasil Pemilihan Umum untuk \\
bisa mengikuti pemilu berikutnya.
\end{tabular}

Dalam perubahan sistem politik pada periode ini, hasilnya tidak memperbesar pertanggungjawaban anggota dewan dan lembaga perwakilan terhadap rakyat yang memberikan mandat terhadapnya. Dalam DPR RI periode ini, sesungguhnya rakyat tidak memiliki instrument yang efektif untuk mengeveluasi anggota dewan selain dari proses penyelenggaraan pemilu. Sehingga, ciri dan sifat utama sistem perwakilan politik di Indonesia pada periode ini tetap kurang menunjukan kemajuan yang berarti dalam hal penguatan hubungan antara rakyat, partai politik, dan wakil-wakilnya di parlemen.

\section{DPR RI Periode 2004-2014}

Pelaksanaan pemilu pada tahun 2004 di Indonesia berdasarkan pada Pasal 22 E ayat 2 UUD 1945 Amandemen Ketiga, yang menyatakan bahwa pemilihan umum diselenggarakan untuk memilih anggota Dewan Perwakilan Rakyat, Dewan Perwakilan Daerah, Presiden dan Wakil Presiden, dan Dewan Perwakilan Rakyat Daerah. sistem pemilihan umum anggota parlemen menurut Pasal 6 Undang-Undang No. 12 Tahun 2003 yang pada intinya menjelaskan pemilu tersebut dilaksanakan dengan sistem proporsional dengan calon daftar terbuka. ${ }^{19}$ Menurut Abdul Bari Azed, sistem

\footnotetext{
${ }^{19}$ Indonesia, Undang-Undang No. 12 Tahun 2003 tentang Pemilihan Umum Anggota DPR, DPD, dan DPRD, Pasal 6 Ayat 1, bahwa Pemilihan Umum memilih anggota DPR, DPRD Propinsi, dan DPRD Kabupaten/Kota dilaksanakan dengan sistem proporsional dengan daftar calon terbuka.
} 
daftar perwakilan proporsional merupakan jenis sistem yang paling lazim dalam sistem perwakilan proporsional. Justru sebagian besar bentuk sistem perwakilan proposional dilaksanakan di distrik yang luas dengan perwakilan legislatif anggota dalam parlemen yang memaksimalkan proporsionalitas dalam sistem pemilihan umum. ${ }^{20}$

Sedangkan yang cukup menarik sistem proporsional di Eropa Kontinental, Amerika Latin, dan Amerika Bagian Selatan menggunakan sistem daftar yang mensyaratkan setiap partai untuk menunjukan daftar kandidatnya kepada para calon konstituen yang hendak memilih. ${ }^{21}$ Para pemilih tersebut memilih partainya, dan bukan memilih kandidatnya. Kemudian partai memperoleh suara secara nasional dalam proporsi andil. Kandidat yang menang diambil dari daftar secara berurutan. ${ }^{22}$ Sistem distrik berwakil ini adalah sistem yang memungkinkan para pemilih dapat mengetahui calon kandidat yang hendak dipilih berdasarkan urutan partai yang ikut serta dalam pemilihan umum.

Berdasarkan apa yang telah diuraikan di atas, dengan demikian menghasilkan sistem proses rekurtmen yang sudah termuat dalam Pasal 67 Undang-Undang No. 12 Tahun 2003 tentang Pemilu 2004, bahwa proses demokrasi dilakukan secara demokratis sesuai dengan ketentuan internal partai politik. Sebab, partai politik memang sudah seharusnya sebagai salah satu organisasi demokrasi yang mengelola proses politik internalnya secara demokratis pula. Dalam periode ini terdapat pula beberapa undang-undang yang berlaku sebagai penunjang sistem politik yang telah diperbaharui berdasarkan Pasal 22 E ayat 2 UUD 1945. Sehingga, konstalasi perpolitikan

\footnotetext{
${ }^{20}$ Abdul Bari Azed dan Makmur Amir, Pemilu dan Partai Politik di Indonesia, Jakarta: Pusat Hukum Tata Negara Fakultas Hukum Universitas Indonesia, 2006, hlm. 70.

${ }^{21}$ Peter Harris dan Ben Reilly, Demokrasi dan Konflik yang Mengakar Sejumlah Pilihan untuk Negosiator, Jakarta: Ameepro, 2000, hlm. 195-198.

22 Abdul Bari Azed dan Makmur Amir, Op. Cit., hlm. 70.
} 
dalam hubungannya antara partai politik dengan lembaga DPR RI semakin progresif. Hal demikian dibuktikan dengan diaktifkannya kembali hak recall bagi partai politik yang memiliki anggota dewan di DPR RI. Apabila terdapat hal-hal yang tidak sejalan dengan visi dan misi partai politik, maka tidak segan partai politik mengajukan penggantian antar waktu (recall) terhadap anggota DPR RI yang bersangkutan. Secara normatif, hal demikian dibentuk untuk menjaga hubungan rakyat dengan wakil rakyat melalui keberadaan fraksi-fraksi di DPR RI, sehingga bilamana anggota dewan keluar dari jalur aspirasi rakyat, maka fraksi dapat mengevaluasi. Namun di sisi lain, justru praktek yang ada ialah oligarki sentralistis terjadi lagi, yaitu partai politik terlalu mengintervensi kadernya yang berada di DPR RI. Sehingga kedaulatan dan sifat indpendensi anggota DPR RI ternodai oleh kepentingan fraksi-fraksi di DPR.

Berkaitan dengan hubungan antara partai politik dengan lembaga DPR RI untuk lebih jelasnya digambarkan melalui tabel, guna memperbandingakan segala perkembangan perubahan undang-undang penunjang sistem politik pada periode 2004 hingga 2014 di Indonesia. Berikut ini tabel menyangkut hubungan antara partai politik dengan DPR RI pada periode 2004-2014 berdasarkan peraturan perundang-undangan yang berlaku sebagai berikut.

\section{Tabel 5. Kategorisasi Hubungan Partai Politik dengan DPR RI Periode}

2004-200923

\footnotetext{
${ }^{23}$ Tabel 5 ini disusun berdasarkan rumusan unsur ada atau tidak adanya hubungan antara partai politik dengan DPR RI yang termuat dalam Undang-Undang No. 22 Tahun 2003 tentang Susduk MPR, DPR, dan DPRD, Undang-Undang No. 31 Tahun 2002 tentang Partai Politik, dan Undang-Undang No. 12 Tahun 2003 tentang Pemilu Anggota DPR, DPD, dan DPRD. Hal yang mendasar dalam periode 2004 hingga 2009 ini, partai politik memiliki kembali hak recall. Terjadinya agregasi kepentingan antara kepentingan rakyat dengan kepentingan fraksi.
} 


\begin{tabular}{|c|c|}
\hline dang- & Hubungan DPR RI dengan Partai Politik \\
\hline $\begin{array}{l}\text { UU No. } 22 \text { Tahun } \\
2003 \text { tentang } \\
\text { Susduk MPR, } \\
\text { DPR, DPD, dan } \\
\text { DPRD }\end{array}$ & $\begin{array}{l}\text { 1. DPR terdiri atas anggota partai politik } \\
\text { peserta pemilihan umum yang dipilih } \\
\text { berdasarkan hasil pemilihan umum. } \\
\text { Dengan kuota sebanyak } 550 \text { orang. } \\
\text { 2. Partai Politik memiliki hak recall atas } \\
\text { anggota DPR RI, dengan langsung } \\
\text { mengusulkan kepada pimpinan DPR RI } \\
\text { dengan diresmikan oleh Presiden. } \\
\text { Anggota DPR RI terhimpun dalam fraksi- } \\
\text { fraksi Partai Politik yang mendapatkan } \\
\text { kursi di DPR RI. }\end{array}$ \\
\hline $\begin{array}{c}\text { UU No. } 31 \text { Tahun } \\
2002 \text { tentang Partai } \\
\text { Politik }\end{array}$ & $\begin{array}{l}\text { 1. Partai politik berhak mengikuti } \\
\text { pemilihan umum untuk mengisi } \\
\text { kekosongan anggota di lembaga } \\
\text { perwakilan. } \\
\text { 2. Partai politik berhak mengusulkan } \\
\text { penggantian antarwaktu (PAW) } \\
\text { anggotanya di lembaga perwakilan } \\
\text { rakyat sesuai dengan peraturan } \\
\text { perundang-undangan. } \\
\text { Partai politik berhak mengusulkan } \\
\text { pemberhentian anggotanya di lembaga } \\
\text { perwakilan rakyat sesuai dengan } \\
\text { peraturan perundang-undangan. }\end{array}$ \\
\hline
\end{tabular}




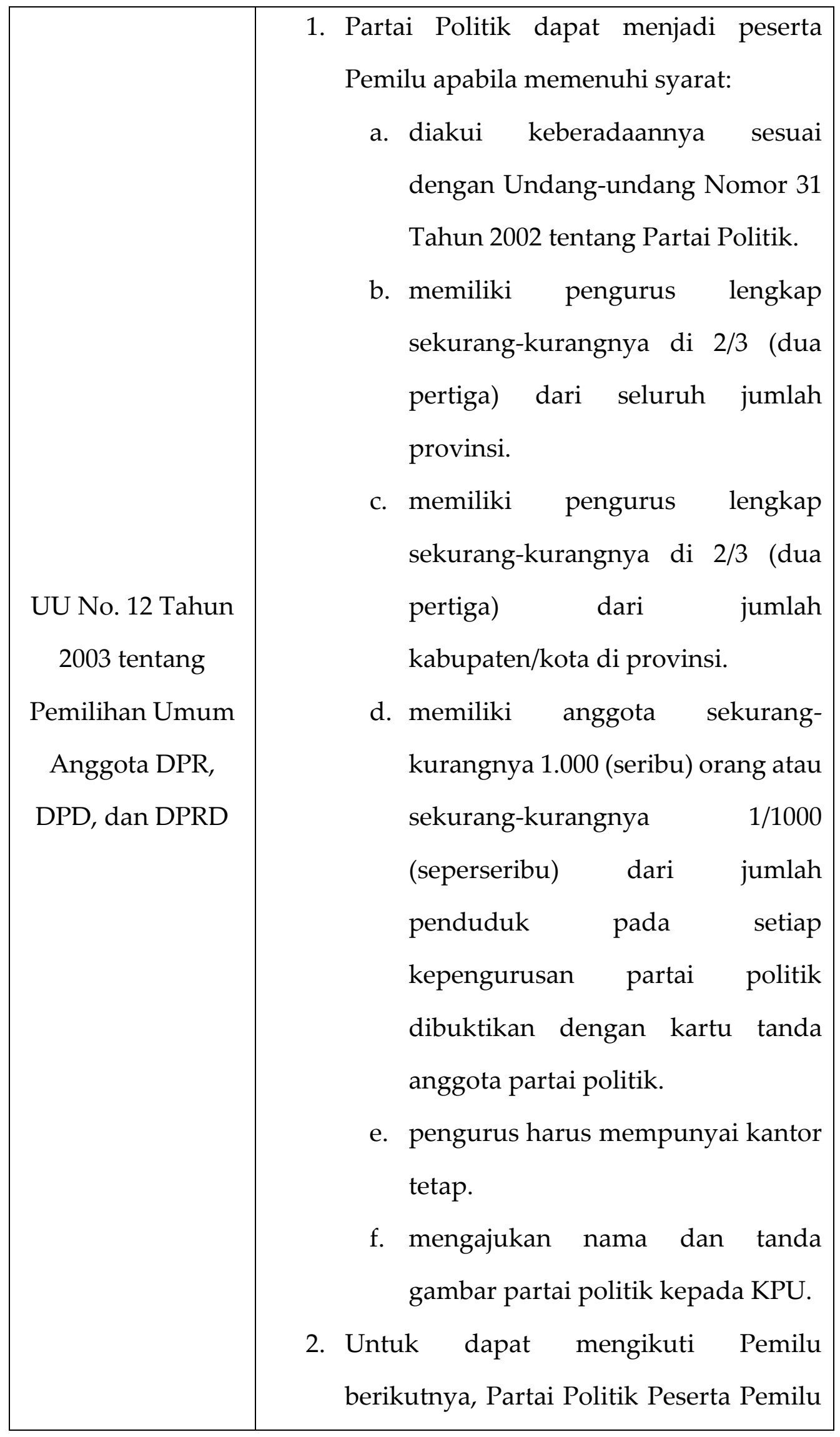


'DIKTUM: JURNAL ILMU HUKUM

ISSN: 2655-3449 (E) - 2338-5413 (P) | Volume 8 No. 1 | Mei 2020 GEDUNG Q FAKULTAS HUKUM UNIVERSITAS PANCASAKTI TEGAL J. Halmahera Km. 01, Kota Tegal | Telepon: (0283) 358745 Website: www.diktum.upstegal.ac.id | email: diktum@upstegal.ac.id

harus memperoleh sekurang-kurangnya

3\% (tiga persen) jumlah kursi DPR.

Tabel 6. Kategorisasi Hubungan Partai Politik dengan DPR RI Periode

$2009-2014^{24}$

\begin{tabular}{|c|c|}
\hline Perundang-undangan & Hubungan DPR RI dengan Partai Politik \\
\hline $\begin{array}{c}\text { UU No. } 23 \text { Tahun } 2009 \\
\text { tentang MD3 }\end{array}$ & $\begin{array}{l}\text { 1. DPR terdiri atas anggota partai politik } \\
\text { peserta pemilihan umum yang dipilih } \\
\text { melalui pemilihan umum. Anggota DPR } \\
\text { berjumlah } 560 \text { (lima ratus enam puluh) } \\
\text { orang. } \\
\text { 2. Partai politik memiliki hak recall terhadap } \\
\text { anggotanya di parlemen. } \\
\text { 3. Setiap anggota DPR harus menjadi } \\
\text { anggota salah satu fraksi. } \\
\text { 4. Fraksi dapat dibentuk oleh partai politik } \\
\text { yang memenuhi ambang batas perolehan } \\
\text { suara dalam penentuan perolehan kursi } \\
\text { DPR. }\end{array}$ \\
\hline $\begin{array}{l}\text { UU No. } 2 \text { Tahun } 2008 \\
\text { tentang Partai Politik }\end{array}$ & $\begin{array}{l}\text { 1. Partai politik berhak mengikuti } \\
\text { pemilihan umum untuk mengisi } \\
\text { kekosongan anggota di lembaga } \\
\text { perwakilan. }\end{array}$ \\
\hline
\end{tabular}

${ }^{24}$ Tabel 6 ini disusun berdasarkan rumusan unsur ada atau tidak adanya hubungan antara partai politik dengan DPR RI yang termuat dalam Undang-Undang No. 23 Tahun 2009 tentang MPR, DPR, dan DPRD, Undang-Undang No. 2 Tahun 2008 tentang Partai Politik, dan Undang-Undang No. 10 Tahun 2008 tentang Pemilu Anggota DPR, DPD, dan DPRD. Hal yang mendasar dalam periode 2009 hingga 2014 ini, partai politik memiliki kembali hak recall. Fraksi dibentuk oleh partai politik dan berhak mengusulkan paket calon pimpinan DPR. 


\begin{tabular}{|c|c|}
\hline & $\begin{array}{l}\text { 2. Partai politik berhak mengusulkan } \\
\text { penggantian antarwaktu (PAW) } \\
\text { anggotanya di lembaga perwakilan } \\
\text { rakyat sesuai dengan peraturan } \\
\text { perundang-undangan. } \\
\text { 3. Partai politik berhak membentuk fraksi } \\
\text { di DPR yang lolos ambang batas. }\end{array}$ \\
\hline $\begin{array}{c}\text { UU No. } 10 \text { Tahun } 2008 \\
\text { tentang Pemilu } \\
\text { Anggota DPR, DPD, } \\
\text { dan DPRD jo UU No. } \\
17 \text { Tahun } 2009 \text { tentang } \\
\text { Penetapan Perpu No. } 1 \\
\text { Tahun } 2009 \text { menjadi } \\
\text { undang-undang. }\end{array}$ & $\begin{array}{l}\text { 1. Partai politik dapat menjadi Peserta } \\
\text { Pemilu setelah memenuhi persyaratan: } \\
\text { a. berstatus badan hukum sesuai } \\
\text { dengan UndangUndang tentang } \\
\text { Partai Politik. } \\
\text { b. memiliki kepengurusan di } 2 / 3 \text { (dua } \\
\text { pertiga) jumlah provinsi. } \\
\text { c. memiliki kepengurusan di } 2 / 3 \text { (dua } \\
\text { pertiga) jumlah kabupaten/kota di } \\
\text { provinsi yang bersangkutan. } \\
\text { d. } \text { menyertakan sekurang-kurangnya } \\
\text { 30\% (tiga puluh perseratus) } \\
\text { keterwakilan perempuan pada } \\
\text { kepengurusan partai politik tingkat } \\
\text { pusat. } \\
\text { e. memiliki anggota sekurang- } \\
\text { kurangnya } 1.000 \text { (seribu) orang atau } \\
\text { kepengurusan partai politik yang }\end{array}$ \\
\hline
\end{tabular}


'DIKTUM: JURNAL ILMU HUKUM

ISSN: 2655-3449 (E) - 2338-5413 (P) | Volume 8 No. 1 | Mei 2020 GEDUNG Q FAKULTAS HUKUM UNIVERSITAS PANCASAKTI TEGAL Jl. Halmahera Km. 01, Kota Tegal | Telepon: (0283) 358745 Website: www.diktum.upstegal.ac.id | email: diktum@upstegal.ac.id

\begin{tabular}{|c|}
\hline dibuktikan dengan kepemilikan \\
kartu tanda anggota. \\
f. mempunyai kantor tetap untuk \\
kepengurusan. \\
g. mengajukan nama dan tanda \\
gambar partai politik kepada KPU. \\
Partai Politik Peserta Pemilu harus \\
memenuhiambang batas perolehan suara \\
sekurang-kurangnya 2,5\% (dua koma \\
lima perseratus) dari jumlah suara sah \\
secara nasional untuk diikutkan dalam \\
penentuan perolehan kursi DPR.
\end{tabular}

Oleh karena itu, pada DPR RI periode 2009-2004 terdapat UndangUndang No. 10 Tahun 2008 tentang Pemilu Anggota DPR, DPD, dan DPRD. Kemudian hal tersebut memperoleh tanggapan masyarakat melalui banyaknya judicial review di Mahkamah Konstitusi. Salah satu materi yang mendapat perhatian publik adalah judical review terhadap Pasal 214 UU No. 10 Tahun 2008. Dalam permohonan uji materiil Perkara No. 22/PUU-VI/2008 dinyatakan bahwa Pasal 214 huruf a, b, c, d, dan e UU No. 10 Tahun 2008 semangatnya telah keluar dari pemilihan umum yang jujur dan adil, karena apabila Pemohon dipilih oleh rakyat ternyata hak Pemohon dipasung oleh pasal tersebut, sehingga suara Pemohon apabila tidak mencapai 30\% (tiga puluh per seratus) dari Bilangan Pembagi Pemilih (BPP) menjadi suara yang sia-sia. ${ }^{25}$

\footnotetext{
${ }^{25}$ Eddhie Praptono, Reconstruction of the Media Law of the Era of Industry Revolution 4.0 Elections, Journal International Conference on Agriculture, Social Sciences, Education Technology and Health, 2020, hlm 175-179.
} 
Selanjutnya pada perkara No. 24/PUU-VI/2008 menyatakan bahwa pada dasarnya setiap pemenang pemilu adalah berdasarkan suara terbanyak, demikian juga seseorang yang terpilih tentu dipilih dan mewakili daerah pemilihannya. Apabila pemenang pemilu tidak didasarkan pada suara terbanyak serta yang terpilih tidak mewakili pemilih maupun daerah pemilihannya tentu hal ini akan merugikan hak konstitusional warga negara yang menjadi peserta pemilu maupun merugikan hak konstitusional para pemilih apabila orang yang dipilihnya tidak mewakili daerahnya. ${ }^{26}$

\section{DPR RI Periode 2014-2019}

Pada demokrasi perwakilan yang terjadi pada proses penyelenggaraan sistem politik periode 2014-2019 terdapat pemahaman yang lebih matang mengenai konsep aspirasi rakyat melalui partai politik dalam lembaga DPR RI. Kemudian, demi menunjang representasi rakyat dan aspirasi rakyat yaitu disusunnya Pasal 69 ayat (2) UU Nomor 17 Tahun 2014 tentang MPR, DPR, DPD, dan DPRD dan Pasal 210 Peraturan DPR RI Nomor 1 Tahun 2014 tentang Tata Tertib yang pada intinya menyatakan bahwa pelaksanaan fungsi-fungsi DPR dijalankan dalam kerangka representasi rakyat. Untuk mengimplementasikan tugas yang diamanatkan oleh peraturan perundangundangan di atas, maka DPR membentuk Tim Mekanisme Penyampaian Hak Mengusulkan dan Memperjuangkan Program Pembangunan Daerah Pemilihan. DPR RI pada masa pasca reformasi di periode 2014-2019 tetap berkomitmen meningkatkan kecepatan dalam memberikan tanggapan atas surat pengaduan dan aspirasi masyarakat yang telah disampaikan melalui fraksi-fraksi yang ada di parlemen. Sesungguhnya aspirasi rakyat merupakan keinginan kuat dari masyarakat yang disampaikan kepada DPR dalam

\footnotetext{
26 Putusan Mahkamah Konstitusi No. 22-24/PUUVI/2008.
} 
bentuk pernyataan sikap, pendapat, harapan, kritik, masukan dan saran terkait dengan tugas, fungsi, dan kewenangan DPR. ${ }^{27}$

DPR RI berdasarkan Pasal 72 huruf g dan Pasal 81 huruf j UndangUndang Nomor 17 Tahun 2014 sebagaimana telah diubah dengan UndangUndang Nomor 42 Tahun 2014 tentang Perubahan Atas Undang-Undang Nomor 17 Tahun 2014 tentang MPR, DPR, DPD, dan DPRD serta Pasal 7 huruf g yang pada intinya menyatakan perlunya meningkatkan kinerja sesuai tugas dan wewenangnya agar dapat bersikap lebih proaktif dan sungguh-sungguh dalam menyerap dan menindaklanjuti aspirasi dan pengaduan yang disampaikan oleh masyarakat. Sehingga turunan dari perundang-undangan tersebut terdapat Pasal 12 huruf j Peraturan DPR RI Nomor 1 Tahun 2014 tentang Tata Tertib sebagaimana telah diubah dengan Peraturan DPR RI Nomor 3 Tahun 2015 di mana fungsi pengawasan DPR salah satunya dilaksanakan dengan cara menyerap, menghimpun, menampung, dan menindaklanjuti aspirasi dan pengaduan masyarakat. Selain itu, UndangUndang Nomor 14 Tahun 2008 tentang Keterbukaan Informasi Publik menjadikan upaya mendekatkan DPR RI dengan rakyat merupakan suatu keharusan. Sehingga, hal demikian tidak lagi hanya mengandalkan keberadaan fraksi sebagai wadah aspirasi rakyat yang terlembaga di DPR RI, namun juga adanya keterbukaan informasi publik guna memenuhi kebutuhan masyarakat atas informasi dari lembaga DPR RI.

Solusi keterbukaan informasi publik tidak serta merta berjalan dengan mulus, sebab bentuk riil penyelenggaraan informasi publik di DPR RI pun tidak berjalan efektif. Maka dari itu, keberadaan partai politik sebagai penghubung langsung ke wakil rakyat perlu dioptimalkan dengan baik dan

\footnotetext{
${ }^{27}$ Indonesia, Langkah DPR Menuju Parlemen Modern dalam Demokrasi Indonesia: Laporan Kinerja DPR (1 Oktober 2014-13 Agustus 2015) Ringkasan, Jakarta: Dewan Perwakilan Rakyat Republik Indonesia, Agustus 2015, hlm. 45.
} 
meminimalisir agregasi kepentingan dari oligarkis sentralis partai politik terhadap anggotanya. Untuk melihat bentuk hubungan yang terjadi di DPR periode 2014-2019 berdasarkan perundang-undangan, maka dapat dilihat dalam tabel berikut ini.

Tabel 7. Kategorisasi Hubungan Partai Politik dengan DPR RI Periode 2014-2019²8

\begin{tabular}{|c|c|}
\hline Per & Hubungan DPR RI dengan Partai Politik \\
\hline $\begin{array}{l}\text { UU No. } 17 \text { Tahun } 2014 \text { jo. } \\
\text { UU No. } 42 \text { Tahun } 2014 \\
\text { tentang MD3 }\end{array}$ & $\begin{array}{l}\text { 1. DPR terdiri atas anggota partai politik } \\
\text { peserta pemilihan umum yang dipilih } \\
\text { melalui pemilihan umum. Anggota DPR } \\
\text { berjumlah } 560 \text { (lima ratus enam puluh) } \\
\text { orang. } \\
\text { 2. Keanggotaan Badan Musyawarah, Badan } \\
\text { Anggaran, dan Badan Legislasi, serta } \\
\text { komisi diusulkan dan dapat dilakukan } \\
\text { penggantian oleh fraksi } \\
\text { bersangkutan pada setiap masa sidang. } \\
\text { 3. Bakal calon pimpinan DPR berasal dari } \\
\text { fraksi atau kumpulan fraksi berupa paket } \\
\text { dan disampaikan dalam rapat paripurna } \\
\text { DPR. }\end{array}$ \\
\hline
\end{tabular}

${ }^{28}$ Tabel 7 ini disusun berdasarkan rumusan unsur ada atau tidak adanya hubungan antara partai politik dengan DPR RI yang termuat dalam Undang-Undang No. 17 Tahun 2014 tentang MPR, DPR, dan DPRD, Undang-Undang No. 2 Tahun 2011 tentang Partai Politik, dan Undang-Undang No. 8 Tahun 2012 tentang Pemilu Anggota DPR, DPD, dan DPRD. Hal yang mendasar dalam periode 2014 hingga 2019 ini, partai politik memiliki kembali hak recall. Terjadinya agregasi kepentingan antara kepentingan rakyat dengan kepentingan fraksi. Dan fraksi memiliki wewenang lebih jauh lagi dalam hal mengusulkan dan mengganti nama-nama anggotanya secara kolektif kolegial dan proporsional di Badan Musyawarah, Badan Legislasi, dan Badan Anggaran, serta komisi-komisi di DPR RI. 


\begin{tabular}{|c|c|}
\hline & $\begin{array}{l}\text { 4. Partai politik memiliki hak recall terhadap } \\
\text { anggota legislatif di DPR RI. }\end{array}$ \\
\hline $\begin{array}{l}\text { UU No. } 2 \text { Tahun } 2011 \\
\text { tentang Perubahan UU } \\
\text { No. } 2 \text { Tahun } 2008 \text { tentang } \\
\text { Partai Politik }\end{array}$ & $\begin{array}{l}\text { 1. Perubahan terjadi pada verifikasi partai } \\
\text { politik, yang harus selesai } 2,5 \text { tahun } \\
\text { sebelum pemilihan umum di tahun } 2014 \text {. }\end{array}$ \\
\hline $\begin{array}{l}\text { UU No. } 8 \text { Tahun } 2012 \\
\text { tentang Pemilihan } \\
\text { Anggota DPR, DPD, dan } \\
\text { DPRD }\end{array}$ & $\begin{array}{l}\text { 1. Partai Politik Peserta Pemilu pada Pemilu } \\
\text { terakhir yang memenuhi ambang batas } \\
\text { perolehan suara dari jumlah suara sah } \\
\text { secara nasional ditetapkan sebagai Partai } \\
\text { Politik Peserta Pemilu pada Pemilu } \\
\text { berikutnya. } \\
\text { 2. Partai politik yang tidak memenuhi } \\
\text { ambang batas perolehan suara pada } \\
\text { Pemilu sebelumnya atau partai politik } \\
\text { baru dapat menjadi Peserta Pemilu } \\
\text { setelah memenuhi persyaratan: } \\
\text { a. berstatus badan hukum sesuai } \\
\text { dengan Undang-Undang tentang } \\
\text { Partai Politik. } \\
\text { b. memiliki kepengurusan di seluruh } \\
\text { provinsi. } \\
\text { (tujuh puluh lima persen) jumlah } \\
\text { babupaten/kota di provinsi yang } \\
\text { miliki kepengurusan di } 75 \% \\
\text { angutan. }\end{array}$ \\
\hline
\end{tabular}




\begin{tabular}{|c|c|}
\hline d. memiliki kepengurusan di $50 \%$ \\
(lima puluh persen) jumlah \\
kecamatan di kabupaten/kota yang \\
bersangkutan. \\
e. menyertakan sekurang-kurangnya \\
$30 \%$ (tiga puluh persen) \\
keterwakilan perempuan pada \\
kepengurusan partai politik tingkat \\
pusat. Partai Politik Peserta Pemilu harus \\
memenuhi ambang batas perolehan \\
suara sekurang-kurangnya 3,5\% (tiga \\
koma lima persen) dari jumlah suara \\
sah secara nasional untuk diikutkan \\
dalam penentuan perolehan kursi \\
anggota DPR
\end{tabular}

Kemudian setelah DPR RI Periode 2014-2019, berikutnya masih ada lagi kategorisasi hubungan DPR dengan partai politik di periode 2019, yaitu berdasarkan Undang-Undang No. 2 Tahun 2018 tentang Perubahan Kedua atas Undang-Undang Nomor 17 Tahun 2014 tentang Majelis Permusyawaratan Rakyat, Dewan Perwakilan Rakyat, Dewan Perwakilan Daerah, dan Dewan Perwakilan Rakyat Daerah bahwa keterlibatan fraksi hampir sama dengan rezim undang-undang sebelumnya, namun yang menjadi menarik ialah adanya perubahan pengaturan mengenai susunan pimpinan DPR yang dari suara terbanyak ke satu, dua, tiga, empat, dan lima. Setelah itu menyangkut ambang batas diatur dalam Pasal 414 UndangUndang No. 7 Tahun 2017 tentang Pemilihan Umum, menyangkut ambang 
'DIKTUM: JURNAL ILMU HUKUM

ISSN: 2655-3449 (E) - 2338-5413 (P) | Volume 8 No. 1 | Mei 2020 GEDUNG Q FAKULTAS HUKUM UNIVERSITAS PANCASAKTI TEGAL Jl. Halmahera Km. 01, Kota Tegal | Telepon: (0283) 358745

batas perolehan suara dalam pemilu serentak ialah $4 \%$ demi menyederhanakan partai politik yang hendak masuk di parlemen. Namun hal yang cukup menarik ialah indeks kepuasan masyarakat terhadap partai politik dengan DPR menempati posisi yang terbawah, sebagai berikut:

\section{Gambar 1. Rilis Survei Nasional 2016 Trust terhadap Institusi}

\section{Demokrasi di Indonesia. ${ }^{29}$}

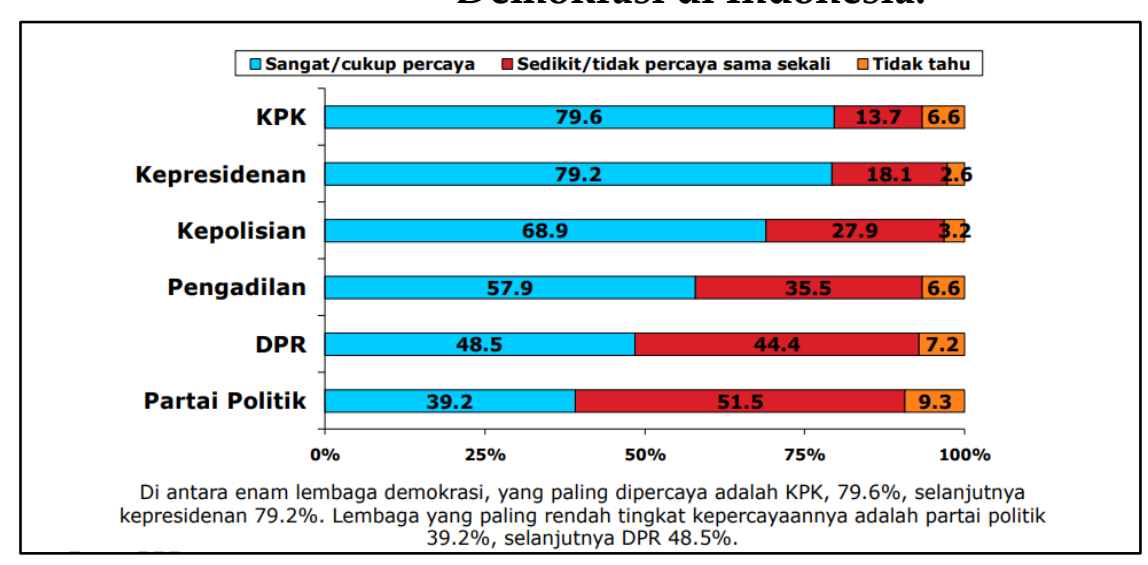

Berdasarkan hal tersebut, penulisan ini menggunakan pendekatan historical dan pendekatan statutes untuk membedah peran serta partai politik dalam hubungannya pada lembaga Dewan Perwakilan Rakyat Republik Indonesia. Oleh sebab itu, keberadaan partai politik tidak boleh serta merta ditiadakan begitu saja, disebabkan perjalanan historinya yang cukup panjang terutama juga pada masa pasca kemerdekaan di Indonesia. Maka dengan demikian sudah secara komprehensif membedah bagian-bagian dalam undang-undang yang berkaitan langsung dengan hubungan antara partai politik dengan DPR RI. Oleh sebab itu, perlu kiranya perbaikan sistem politik di Indonesia dijaga dengan baik dan juga perlu terus memperbaharui sistem yang merepresentasikan kepentingan rakyat Indonesia demi terciptanya tujuan Bangsa Indonesia di masa yang akan datang.

\footnotetext{
${ }^{29}$ Indikator Politik Indonesia, Rilis Survei Nasional 2016: Trust terhadap Institusi Demokrasi di Indonesia, Jakarta: Indikator, 2016), hlm. 11, sumber https :// indicator .co.id /uploads /20160208141409. Bahan_Rilis_Indi_KPK. Pdf, diakses pada tanggal 07 April 2019, pukul 14.37 WIB
} 


\section{Simpulan}

1. Peranan partai politik ialah sebagai wadah yang strategis dalam sistem politik di Indonesia guna penghubung antara proses pembentukan kebijakan pemerintah baik di eksekutif maupun di legislatif dengan warga negaranya. Sesungguhnya justru partai politiklah yang menentukan terselenggara atau tidaknya sistem demokrasi di Indonesia. Sebab dalam partai politik terdapat bentuk pelembagaan wujud ekspresi ide-ide, pikiran-pikiran, pandangan, dan keyakinan bebas dalam masyarakat yang demokratis. Selain itu, peranan partai politik sebagai media dan wahana sangat signifikan. Kemudian partai politik juga menurut peraturan perundang-undangan yang berlaku dalam sejarah perkembangan partai politik pasca reformasi ialah berfungsi sebagai pendidikan politik, menyerap, menyalurkan dan memperjuangkan kepentingan masyarakat, serta mempersiapkan anggota masyarakat untuk mengisi jabatan-jabatan politik sesuai dengan mekanisme demokrasi yang ada di Indonesia melalu demokrasi perwakilan.

2. Pada pola hubungan antara partai politik dengan DPR RI cukup sederhana, yaitu partai politik memiliki hak untuk ikut serta dalam proses pemilihan umum anggota legislatif di DPR RI, kemudian di dalam lembaga DPR yaitu terdiri atas anggota partai politik peserta pemilihan umum yang dipilih melalui pemilihan umum, partai politik memiliki hak recall terhadap anggotanya di parlemen, setiap anggota DPR harus menjadi anggota salah satu fraksi, dan partai politik berhak membentuk fraksi di DPR RI guna menjaga keberlangsungan pelaksanaan visi-misi partai serta aspirasi rakyat di DPR RI. 


\section{DIK StouM}

\section{Daftar Pustaka}

\section{Buku :}

Amir, Makmur dan Reni Dwi Purnomowati. Lembaga Perwakilan Rakyat. Jakarta: Pusat Hukum Tata Negara Fakultas Hukum Universitas Indonesia. 2005.

Asshiddiqie, Jimly. Kemerdekaan Berserikat Pembubaran Partai Politik dan Mahkamah Konstitusi. Jakarta: Konstitusi Press. 2005.

Asshiddiqie, Jimly. Hukum Tata Negara dan Pilar-Pilar Demokrasi: Serpihan Pemikiran Hukum, Media, dan HAM. Jakarta: Konstitusi Press. 2005.

Azed, Abdul Bari (ed). Sistem-sistem Pemilihan Umum: Suatu Himpunan Pemikiran. Jakarta: BPFH UI. 2000.

Azed, Abdul Bari dan Makmur Amir. Pemilu dan Partai Politik di Indonesia. Jakarta: Pusat Hukum Tata Negara Fakultas Hukum Universitas Indonesia. 2006.

Budiardjo, Miriam. Partisipasi dan Partai Politik: Sebuah Bunga Rampai. Jakarta: Gramedia. 1982.

Budiardjo, Miriam. Dasar-Dasar Ilmu Politik. Jakarta: Gramedia. 1991.

Budiardjo, Miriam. Pengantar Ilmu Politik. Jakarta: Gramedia. 2000.

Chotib, dsb. Kewarganegaraan 2: Menuju Masyarakat Madani. Jakarta: Yudhistira. 2007. Harris, Peter dan Ben Reilly. Demokrasi dan Konflik yang Mengakar Sejumlah Pilihan untuk Negosiator. Jakarta: Ameepro. 2000.

Irsham, Mahrus dan Lili Romli. Menggugat Partai Politik. Jakarta dan Depok: Fitroh Printing dan LIP Fisip Universitas Indonesia. 2003.

Legowo, T.A. (ed). Lembaga Perwakilan Rakyat di Indonesia: Studi Analisis Sebelum dan Setelah Perubahan UUD 1945 (Kritik, Masalah, dan Solusi). Jakarta: FORMAPI. 2005.

Meny, Yves Meny and Andrew Knapp. Government and Politics in Western Europe: Britain, France, Italy, German. Third Section. Oxford: Oxford University Press, 1998. 
Michels, Robert. Political Parties, A Sosiological Study of the Oligarchical Tendecies of Modern Democracy (terjemahan). Jakarta: Rajawali. 1984.

Muljana, Slamet. Nasionalisme Sebagai Modal Perjuangan. Jakarta: Balai Pustaka. 1968. Monica and Jean Carlot. 'Les Groupes Politiques dans leur Environement in J.Leca and M. Grawitz (eds.). Traite de Science Politique, iii. Paris: PUF. 1985.

Poerwanta, PK. Partai Politik di Indonesia. Jakarta: Rineka Cipta. 1994.

Puspoyo, Widjanarko. Dari Soekarno Hingga Yudhoyono: Pemilu Indonesia 1955-2009. Solo: Era Adicitra Intermedia. 2012.

Syafiie, Inu Kencana. Pengantar Ilmu Pemerintahan. Bandung: Refika Aditama. 2001.

\section{Jurnal}

Eddhie Praptono dan Erwin Aditya Pratama, Reconstruction of the Media Law of the Era of Industry Revolution 4.0 Elections, Journal International Conference on Agriculture, Social Sciences, Education Technology and Health, 2020.

\section{Makalah :}

Dewan Perwakilan Rakyat Republik Indonesia. Langkah DPR Menuju Parlemen Modern dalam Demokrasi Indonesia: Laporan Kinerja DPR (1 Oktober 2014-13 Agustus 2015) Ringkasan. Jakarta: Dewan Perwakilan Rakyat Republik Indonesia. Agustus 2015.

Indikator Politik Indonesia. Rilis Survei Nasional 2016: Trust terhadap Institusi Demokrasi di Indonesia. Jakarta: Indikator. 2016. sumber https :// indicator .co.id /uploads /20160208141409. Bahan_Rilis_Indi_KPK. Pdf, diakses pada tanggal 07 April 2019, pukul 14.37 WIB.

\section{Peraturan Perundang-Undangan dan Putusan :}

Indonesia, Undang-Undang Dasar 1945 (Asli).

Indonesia, Undang-Undang Dasar 1945 (Setelah Amandemen).

Indonesia, Undang-Undang No. 2 Tahun 1999 tentang Partai Politik. Lembaran Negara Republik Indonesia Tahun 1999 Nomor 22. 
Indonesia, Undang-Undang No. 31 Tahun 2002 tentang Partai Politik. Lembaran

Negara Republik Indonesia Tahun 2002 Nomor 138.

Indonesia, Undang-Undang No. 2 Tahun 2008 tentang Partai Politik. Lembaran

Negara Repubik Indonesia Tahun 2008 Nomor 2.

Indonesia, Undang-Undang No. 2 Tahun 2011 tentang Perubahan Undang-Undang

No. 2 Tahun 2008 tentang Partai Politik. Lembaran Negara Republik Indonesia Tahun 2011 Nomor 8.

Indonesia, Undang-Undang No. 4 Tahun 1999 tentang Susunan dan Kedudukan MPR, DPR, dan DPRD, Lembaran Negara Republik Indonesia Tahun 1999 Nomor 24.

Indonesia, Undang-Undang No. 22 Tahun 2003 tentang Susunan dan Kedudukan MPR, DPR, dan DPRD, Lembaran Negara Republik Indonesia Tahun 2003 Nomor 92.

Indonesia, Undang-Undang No. 23 Tahun 2009 tentang MPR, DPR, dan DPRD, Lembaran Negara Republik Indonesia Tahun 2009 Nomor 123.

Indonesia, Undang-Undang No. 17 Tahun 2014 tentang MPR, DPR, dan DPRD, Lembaran Negara Republik Indonesia Tahun 2014 Nomor 383.

Indonesia, Undang-Undang No. 2 Tahun 2018 tentang Perubahan Kedua UndangUndang No. 17 Tahun 2014 tentang MPR, DPR, DPD, dan DPRD, Lembaran Negara Republik Indonesia Tahun 2018 Nomor 29.

Indonesia, Undang-Undang No. 3 Tahun 1999 tentang Pemilihan Umum, Lembaran Negara Republik Indonesia Tahun 1999 Nomor 23.

Indonesia, Undang-Undang No. 12 Tahun 2003 tentang Pemilihan Umum Anggota DPR, DPD, dan DPRD, Lembaran Negara Republik Indonesia Tahun 2003 Nomor 37.

Indonesia, Undang-Undang No. 10 Tahun 2008 tentang Pemilihan Umum Anggota DPR, DPD, dan DPRD, Lembaran Negara Republik Indonesia Tahun 2008 Nomor 51. 


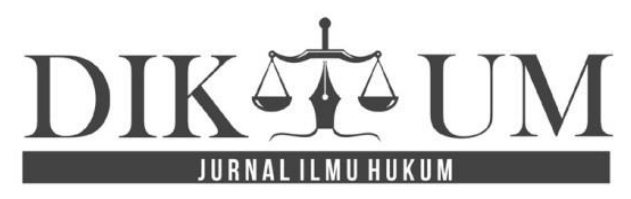

'DIKTUM: JURNAL ILMU HUKUM

ISSN: 2655-3449 (E) - 2338-5413 (P) | Volume 8 No. 1 | Mei 2020

GEDUNG Q FAKULTAS HUKUM UNIVERSITAS PANCASAKTI TEGAL

Jl. Halmahera Km. 01, Kota Tegal | Telepon: (0283) 358745

Indonesia, Undang-Undang No. 8 Tahun 2012 tentang Pemilihan Umum Anggota

DPR, DPD, dan DPRD, Lembaran Negara Republik Indonesia Tahun 2012

Nomor 117.

Indonesia, Undang-Undang No. 7 Tahun 2017 tentang Pemilihan Umum, Lembaran

Negara Republik Indonesia Nomor 182.

Indonesia, Putusan Mahkamah Konstitusi No. 22-24/PUUVI/2008. 